\title{
Contemporary Interpretation of the Conception of World Heritage in International Law and Practice
}

\begin{abstract}
This presentation examines some of the complex issues that pertain to the perspective of the conception of World Heritage embodied in the UNESCO Convention concerning the Protection of the World Cultural and Natural Heritage closely related to the currently observed changes in its conceptual development. By today, it has become the most widely accepted international instrument demonstrating successful implementation on different levels. At the same time, new issues regarding new categories of objects, responsibility etc. have emerged. Conclusions are drawn in favour of an adequate re-examination and re-adaptation of the conceptual framework of cultural heritage based on accepting its new functional dimension and integrating multiple perspectives from a variety of academic fields.
\end{abstract}

Keywords: world cultural and natural heritage, common heritage of mankind, World Heritage Committee, World Heritage Fund, World Heritage List of UNESCO, responsibility, erga omnes obligation, international community, cultural landscapes

The conception of "World Cultural Heritage" appeared in international law and practice in the late " $60 \mathrm{~s}$ of $20^{\text {th }}$ century. The main idea of the conception is that certain states are credited with cultural assets and these states have the duty to maintain and protect them in the interest of the whole humankind ${ }^{1}$ for future generations. Thus, states are merely trustees of the treasures of importance for the whole humanity. As a result, the state in which the object is situated has the duty to protect it and prevent its destruction. If the state is not able to provide sufficient protection, it is obliged to request the international community of states for assistance. International instruments often regard cultural heritage as the common heritage of mankind. Thus, the Declaration of the Principles of International Cultural Cooperation (1966) confirms that "all cultures are part of the common heritage of mankind, and accordingly, the tangible forms of such cultures are cultural monuments". The UNESCO Universal Declaration on Cultural Diversity (2001) recognises cultural diversity as a source of exchange, innovation and creativity and the common heritage of humanity. ${ }^{2}$

The concept of cultural heritage has expanded considerably in recent years. This greatly increased popular attention is based on an ever-increasing public awareness of the richness of heritage as well as of its vulnerability. Today, information and communication technologies along with tourism facilitate a better response to this social demand. For heritage must be appropriated and made accessible in more imaginative ways, shared more widely within and among nations, used more creatively to re-invent a living culture (which will soon be valued as the heritage of the future) and last but not least, nurtured more wisely as an important source of income and employment. Yet today, the gap between ends and

\footnotetext{
* Candidate in legal science in Koretsky Institute of Political and Legal Sciences of National Academy of Sciences of Ukraine, Ukraine, Triohsvyatitelska str., 4.

E-mail: Elya.Melnychuk@gmail.com

1 Fechner, F. G.: The Fundamental Aims of Cultural Property Law. International Journal of Cultural Property, 7 (1998) 388.

2 http://www.unesco.ru
} 
means is even larger: wars, natural disasters, urbanization and industrialization continue to jeopardize cultural heritage and its relationship with development has become increasingly complex. In the modern world of global markets, national and international rules must be harmonized, thus, an effective system for the protection of cultural property should incorporate different branches of law.

The United Nations Educational, Scientific and Cultural Organization (UNESCO) was bound to encourage the identification, protection and preservation of cultural and natural heritage around the world considered to be of outstanding value to humanity. Concrete action began in 1960 with an international campaign to save the temples of Nubia, a landmark operation that was notably followed by campaigns in Venice (1966), Carthage, Borobudur (1970) and Angkor (1991). The great scale and spectacular repercussions of these enterprises rallied unprecedented contributions in favour of threatened sites.

The successful international campaigns furthered working out an international legal instrument regarding the international protection of cultural heritage. At the same time, the International Union for Conservation of Nature and Natural Resources (hereinafter: IUCN) paid great attention to deteriorating natural objects, scilicet, national parks, reservations, outstanding natural sights, the protection of which was obviously needed. An international conference in Stockholm (1972) approved of the proposal to adopt an international instrument of international cooperation in respect of cultural property and natural objects.

The recognition of the need to establish a universally recognized ethical-legal foundation so as to safeguard world heritage along with the concurrent activity of the IUCN prompted the UNESCO to examine the subject further with the Convention pertaining to the Protection of Cultural and Natural World Heritage adopted in 1972. Today, there are 186 State Parties to the Convention and its universal application makes the concept of World Heritage exceptional.

According to Para. 1 of Art. 6 of the Convention, whilst it fully respects the sovereignty of the states on whose territories the cultural and natural heritage is situated and without prejudice to property rights provided by national legislation, each State Party to the Convention recognizes that the duty of ensuring conservation of the elements of world heritage situated on its territory lies primarily with it and undertakes to act to this end. This fundamental provision is the basis of international law concerning the protection of cultural values.

For this purpose, each State Party to the Convention is required to compile an inventory of property forming part of cultural and natural heritage, which is situated on its territory and suitable for protection under the Convention. The duty of ensuring the identification, protection, conservation, presentation and transmission to future generations of cultural and natural heritage situated on their territories is also recognized by states as a measure of national protection. Thus, the state is responsible for the protection of values composing world heritage. Such state employs the utmost of its own resources. The core obligation of protection, conservation and transmission to future generations incumbent on a State Party according to the World Heritage Convention in respect of monuments, groups of buildings and sites of outstanding universal value situated on its territory constitutes an obligation recognized by general international law. ${ }^{3}$ Each State Party should endeavour to take the appropriate legal, scientific, technical, administrative and financial measures necessary for the identification, protection, conservation, presentation and rehabilitation of such heritage.

3 O'Keefe, R.: World Cultural Heritage: Obligation to the International Community as a Whole? International \& Comparative Law Quarterly, January, 2004. 193. 
At the same time, State Parties undertake to contribute to the identification, protection, conservation and preservation of world cultural and natural heritage, if the state on whose territory it is situated is so requested and do not take any deliberate measures which might damage directly or indirectly the cultural and natural heritage situated on the territory of other State Parties to the Convention. It means the positive responsibility, that is, the duties of the Parties to the Convention. The provisions of the Convention instantiate a "delicate balance between national sovereignty and international intervention". ${ }^{4}$

Apart from specific safeguarding actions, the most significant achievement has been the adoption of a permanent instrument of international cooperation, where there had not been one before. The result, in effect, is a commitment to solidarity, which is at the heart of the notion of world heritage. ${ }^{5}$ The Convention stipulates the duty "of the international community as a whole to cooperate" (Art. 6), which should be achieved via the establishment of a "system of international cooperation and assistance" (Art. 7). Such system is created by an Intergovernmental Committee for the Protection of the World Cultural and Natural Heritage of Outstanding Universal Value, the World Heritage Committee (hereinafter: the Committee), which was established via the Convention. Its Rules of Procedure were adopted by the Committee at its first session (Paris, 1977). Its members are elected by the General Assembly of the State Parties to the Convention ensuring "an equitable representation of the different regions and cultures of the world" (Art. 8). With its 21 members, the Committee is the final decision-making body, the responsibilities of which include establishing, keeping up to date and publishing both the "World Heritage List" and the "List of World Heritage in Danger", furthermore, administering the World Heritage Fund (Art. 15) and deciding on granting financial assistance (Art. 13, 21). The World Heritage Centre appointed by the Director-General of the UNESCO assists the Committee to perform its task (Art. 14). Under Art. 29 of the Convention, the Committee submits a report on its activities at each General Assembly of State Parties and at each of the ordinary sessions of the General Conference of the UNESCO.

The Convention refers only to the immovable and tangible heritage, whether "cultural" (Art. 1 - monuments, groups of buildings, sites) or "natural" (Art. 2). On the basis of national inventories (an inventory of property forming part of the cultural and natural heritage situated on the state's territory), the World Heritage Committee has established the World Heritage List. The World Heritage List consists of cultural and natural sites. They include the Palace and Park of Versailles (France), Stonehenge, Avebury and associated sites, the Tower of London, (the United Kingdom of Great Britain), the Wet Tropics of Queensland, Shark Bay (Australia), the Vilnius Historic Centre, the Kernave Archaeological Site (Lithuania), the Acropolis, Athens, the Archaeological Site of Delphi, the Medieval City of Rhodes (Greece), the Archaeological site of Troy (Turkey), the Saint-Sophia Cathedral and Kiev-Pechersk Lavra, the Ensemble of the Historic Centre of Lviv (Ukraine) and others. ${ }^{6}$ Today, the List of World Heritage consists of 890 sites, including 689 cultural, 176 natural objects and 25 mixed properties in 148 State Parties. The Convention does not set a numerical limit for the List.

4 Cameron, C.: The Strengths and Weaknesses of the World Heritage Convention. Nature and Resources, 28 (1992) 3, 18-21.

5 Musitelli, J.: Opinion World Heritage, between Universalism and Globalization. International Journal of Cultural Property, 11 (2002) 326.

6 Ibid. 
The nominations presented to the Committee shall entail the full commitment of the State Party to preserve the heritage concerned within its means. Such commitment shall take the form of appropriate policy, legal, scientific, technical, administrative and financial measures proposed and adopted to protect the property and its outstanding universal value.

The Convention is not intended to ensure the protection of all properties of great interest, importance or value, but only of a selection of the most outstanding of these from an international viewpoint. It cannot be assumed that a property of national and/or regional importance will be automatically included in the World Heritage List.

Outstanding universal value means cultural and/or natural significance, which is so exceptional as to transcend national boundaries and to be of common importance for present and future generations of all humanity. As such, the permanent protection of this heritage is of the highest importance to the international community as a whole. The Committee defines the criteria for the inclusion of properties in the World Heritage List under the Operational Guidelines for the Implementation of the World Heritage Convention (January, 2008). ${ }^{7}$ The Operational Guidelines are periodically revised to reflect the decisions of the World Heritage Committee.

The Convention does nor specify clear guidelines regarding the deletion of property from the List, whereas, it is Art. 11 (2) that refers to the task of the Committee to "establish, keep up to date and publish" the List. These tasks also include deletion as the Committee drafted it under extensive provisions in the Operational Guidelines. Some paragraphs of the Chapter of Operational Guidelines, that is, the "Procedure for the eventual deletion of properties from the World Heritage List" are devoted to that purpose.

The Committee adopted a procedure for the deletion of properties from the World Heritage List in cases:

a) where the property has deteriorated to the extent that it has lost those characteristics which determined its inclusion in the World Heritage List; and

b) where the intrinsic qualities of a World Heritage Site were already threatened at the time of its nomination by action of man and where the necessary corrective measures as outlined by the State Party at the time have not been taken within the time proposed.

The Committee will examine all the information available and will take a decision. Such a decision shall, in accordance with Art. 13 (8) of the Convention, be taken by a majority of two-thirds of its members present and voting.

The Guidelines do not seem to require the consent of the State Party concerned, only its consultation shall be achieved. The Committee shall not decide to delete any property, unless the State Party has been consulted on the question. The Committee shall not apply the deletion procedure as an alternative to the inscription of sites on the List in Danger.

The State Party shall be informed of the Committee's decision and public notice of such a decision shall be immediately given by the Committee. If the Committee's decision entails any modification to the World Heritage List, this modification will be reflected in the next updated List that is published.

For a long time, deletions have not been implemented, by reason of political and legal deliberations. ${ }^{8}$ The Committee has refrained from setting an example-a decision

7 Ibid.

8 Strasser, P.: Putting Reform into Action-Thirty Years of the World Heritage Convention: How to Reform a Convention without Changing its Regulations. International Journal of Cultural Property, 7 (1998). 
which may cause political repercussions and irritations. An example of the deletion procedure took place in 2007: The World Heritage Committee de-listed a property because of Oman's decision to reduce the size of the protected area by $90 \%$ in contravention of the Operational Guidelines of the Convention. This was seen by the Committee as destroying the outstanding universal value of the site, which was inscribed in 1994. In 1996, the number of the population of the Arabian Oryx on the site had been 450, but it dwindled to 65 with only about four breeding pairs, which makes its future viability uncertain. This decline was due to poaching and habitat degradation. ${ }^{9}$

After extensive consultations with the State Party, the Committee held that the unilateral reduction of the size of the Sanctuary and plans to proceed with hydrocarbon prospecting would destroy the value and integrity of the property, which is also home to endangered species including the Arabian Gazelle and the houbara bustard.

The second instance of deletion has taken place in 2009, when the World Heritage Committee decided to remove Germany's Dresden Elbe Valley from the UNESCO's World Heritage List due to the construction of a four-lane bridge in the heart of the cultural landscape, which meant that the property failed to keep its "outstanding universal value as inscribed". ${ }^{10}$

Dresden was inscribed as a cultural landscape in 2004. The Committee held that Germany could present a new nomination related to Dresden in the future. In doing so, the Committee recognized that parts of the site might be considered to be of outstanding universal value, but that it would have to be presented under different criteria and boundaries.

The Convention of 1972 foresees the establishment of the List of World Heritage in Danger. The World Heritage Committee includes property "appearing in the World Heritage List, for the conservation of which major operations are necessary and for which assistance has been requested under the Convention". Sites can be listed, if they are threatened by natural disasters such as floods and volcanic eruptions, earthquakes, serious fires, and they can be listed because of human-caused disasters such as urbanization, changing land ownership, tourism and armed conflicts. The List was criticized as not paying tribute to the real situation. Its inclusion of only about 35 inscribed sites does not reflect the dangers and threats with which World Heritage is faced or as described, for example, in the List of 100 Most Endangered Sites compiled by the World Monument Fund. ${ }^{11}$

9 The Arabian Oryx Sanctuary is an area within the bio-geographical regions of the Central Desert and Coastal Hills in Oman. Seasonal fogs and dews support a unique desert ecosystem, the diverse flora of which includes several endemic plants. Its rare fauna includes the first free-ranging herd of the Arabian Oryx with the global extinction of the species in the wild in 1972 and its reintroduction here in 1982. The only wild breeding sites in Arabia of the endangered houbara bustard and a species of wader are also to be found here as well as the Nubian ibex, the Arabian wolves, honey badgers, caracals and the largest wild population of the Arabian gazelle.

10 The $18^{\text {th }}$ and $19^{\text {th }}$ century cultural landscape of the Dresden Elbe Valley stretches some $18 \mathrm{kms}$ along the river from Übigau Palace and Ostragehege fields in the north-west to the Pillnitz Palace and the Elbe River Island in the south-east. The property, which features low meadows and is crowned by the Pillnitz Palace as well as numerous monuments and parks from the $16^{\text {th }}$ to $20^{\text {th }}$ centuries in the city of Dresden was inscribed on the List of World Heritage in Danger in 2006 because of the planned construction of the Waldschlösschen Bridge.

11 Ibid. 252. 
One of the main functions of the World Heritage Committee is to administer the World Heritage Fund and to determine how financial resources are to be allocated to the countries and organizations which request assistance (according to Art. 15). Moneys accumulated in the Fund come from: 1) obligatory contributions from State Parties to the Convention, which are fixed at one percent of their contribution to the budget of the UNESCO; 2) from voluntary contributions from State Parties; 3) donations from institutions or private individuals or from promotional activities. The World Heritage Fund provides assistance on grounds of concrete provisions, as the international institute can't satisfy all requests for international financial assistance with regard to limited resources. The Convention of 1972 foresees arrangements for international assistance such as studies concerning artistic, scientific and technical problems, training of staff and specialists, supply of equipment and so on. The benefit of the Fund consists in the allocation of finances to the mechanisms of assistance. $^{12}$

In 1997, the General Conference of the UNESCO adopted the Declaration on the Responsibilities of the Present Generations towards Future Generations, Art. 7 of which states in part that "the present generations have the responsibility to identify, protect and safeguard the tangible cultural heritage and to transmit this common heritage to future generations". ${ }^{13}$ Customary norms lay in the principle that the preservation of cultural heritage constitutes part of the general interest of the international community as a whole. This principle has its theoretical foundation in the concept of erga omnes obligations formulated by the International Court of Justice in the well-known Barcelona Traction case. In this case, the Court distinguished between norms that create bilateral obligations of reciprocal character binding upon individual states inter se and norms that create international obligations erga omnes or obligations owing to all states in the public interest. The prohibition of acts of wilful and systematic destruction of cultural heritage of great importance for humanity also falls under the category of erga omnes obligations. ${ }^{14}$ On the other hand, the "international community as a whole" is an abstraction. There is no legal entity or person by that name. As Sir Gerald Fitzmaurice put it in his trenchant dissenting opinion in the Namibia case in 1971, "the so-called organized world community is not a separate juridical entity with a personality over and above, and distinct from, the particular international organizations in which the idea of it may from time to time find actual expression". ${ }^{15}$

According to the GA UN Res. 56\589 12 December 2001, the breach of an international obligation of the State constitutes an internationally wrongful act, which entails the international responsibility of that State. Under Art. 42 of the GA UN Res. 2001, a State as an injured state is entitled to invoke the responsibility of another state, if the obligation breached owes to a group of states including that state or the international community as a whole. This provision is a substantial step in the progressive development of international

12 Musitelli: op. cit. 326.

13 Declaration on the Responsibilities of the Present Generations towards Future Generations, 12 Nov. 1997: UNESCO DOC 29 C / Res 44.

14 Francioni, F.-Lenzerini, F.: The Destruction of the Buddhas of Bamiyan and International Law. European Journal of International Law, 14 (2003) 619-651.

$15 C f$., Judge Fitzmaurice (dissenting) in the Namibia Opinion, I.C.J. Reports, 1971. 12 at 241 (Para. 33). 
law as Law of the International Community. ${ }^{16}$ Thus, the prescription of collective measures in the common interest of the states is the first task. ${ }^{17}$

Art. 48 foresees the invocation of responsibility by a state other than an injured state: "any state other than an injured state is entitled to invoke the responsibility of another state, if the obligation breached owes to a group of states including that state and it is established for the protection of the collective interest of the group, or if the obligation breached owes to the international community as a whole."

By virtue of its non-synallagmatic nature and of the Convention's express textual references to a universal interest in the preservation of the cultural heritage in question, the obligation laid down in Art. 4 is an obligation owing to all State Parties to the Convention and it is established for the protection of a collective interest of the group" according to the phrasing of Art. 48 (1) (a) of the International La Commission's Articles on the Responsibility of States for Internationally Wrongful Acts. It is an erga omnes partes obligation, to use the traditional terminology. ${ }^{18}$

Having established this, it becomes apparent which subjects of international law are injured by such violation. International norms related to cultural heritage consider the destruction of any nation's cultural property as a loss and an injury to the collective heritage of humankind's civilization. The duty not to destroy cultural heritage, therefore, is merely a manifestation of an erga omnes obligation.

Few events have caused such a great shock and condemnation within the international community in recent years as the destruction of the great Buddhas of Bamiyan in 2001. Mullah Mohammed Omar issued the order for the destruction of all "statues", which were "un-Islamic". His main target was a 1,500-year-old statue of Buddha in the central Afghan province of Bamiyan. This 53-meter-high sculpture, carved into a cliff face, was the most famous landmark in Afghanistan and the most visible testimony to the country's Buddhist past before the arrival of Islam in the ninth century. It was one of the few historical treasures to have survived the country's turbulent and violent history. ${ }^{19}$

It is important to point out that while at the relevant time there were no Afghan properties inscribed on the World Heritage List, Art. 12 of the Convention states expressly that the fact that a property belonging to the cultural or natural heritage has not been included in either the World Heritage List or in the List of World Heritage in Danger shall in no way be construed to mean that it does not have an outstanding universal value for purposes other than those resulting from inclusion in these lists. This provision must be read in connection with Art. 4, which points out: the duty of ensuring the protection, conservation, presentation and transmission to future generations of the cultural heritage situated on the territory of each State Party to this Convention belongs primarily to that state.

The joint reading of these provisions makes it clear that membership in the World Heritage Convention obliges State Parties to conserve and protect their own cultural properties, even if these are not inscribed in the World Heritage List. As for the Bamiyan

16 Лукашук И. И.: Право международной ответственности [The Law of Internation Responsibility]. Moszkva, 2004, 300.

17 Лукашук И. И.: Глобализачия, государство и право ХХІ век [Globalisation, State and Law of the 21st Century]. Moszkva, 2000.

18 O'Keefe: op. cit. 190.

19 Amin, S.-Ramesh, Th.: Vandalism in Afghanistan and No One to Stop It. The International Herald Tribune, Tuesday, March 6, 2001. 
Buddhas, there is no doubt that they were included in the concept of cultural heritage relevant to the Convention. Regardless of whether they meet the standard of 'outstanding universal value' set forth in Art. 1, the Buddhas were certainly 'works of monumental sculpture' and of generally recognized historical importance.

Individual states, international organizations, such as the United Nations and the UNESCO, religious authorities including some of the most influential Islamic authorities, NGOs and people all over the world have called for international mobilization against such acts of barbarity and religious intolerance. First of all, such destruction gives rise to a breach of duties falling to Afghanistan under its membership to the 1972 World Heritage Convention. According to the Preamble of this Convention, "deterioration or disappearance of any item of cultural heritage constitutes a harmful impoverishment of the heritage of all the nations of the world".

Having established this, it becomes apparent which subjects of international law are thus injured by such violation. International norms related to cultural heritage consider the destruction of any nation's cultural property as a loss and an injury to the collective heritage of humankind's civilization. The duty not to destroy cultural heritage, therefore, is a manifestation of an erga omnes obligation. In the Afghan case, the erga omnes character of the obligation is confirmed by the fact that there is no directly and materially injured third state, since the act of violence is committed on the territory and against a value belonging to the transgressor state as such. In other words, faced with a customary obligation limiting the power that the territorial state has over assets that belong to its sovereignty, such an obligation may exist only with regard to the international community as a whole, and thus, with regard to all states. It follows that every state, unilaterally or in the context of an international organization, could have adopted appropriate measures as a reaction to the wrongful act committed by the Taliban against the cultural heritage located on its territory. ${ }^{20}$

There is no doubt that the deliberate, wanton destruction of the great Buddhas is inconsistent with the letter and spirit of the 1972 Convention. The World Heritage Committee, in its aforementioned 1997 resolution, had considered the statues to be of 'inestimable value' and 'not only part of the heritage of Afghanistan, but part of the heritage of humankind'. Therefore, there is sufficient legal basis for the adoption of countermeasures, such as the suspension of technical assistance, withdrawal of financial aid and similar measures by states party to the World Heritage Convention and by the UNESCO.

The catalogue and inventory of national treasures are generally intended to limit such private rights in view of safeguarding the public interest in the conservation and transmission of the cultural heritage to future generations. In the case of the Buddhas of Bamiyan, the injury to the international public interest, which was to conserve these monuments and prevent their destruction, was all the more apparent because a) the destruction was motivated by invidious and discriminatory intent; b) it was systematic; and c) it was carried out in blatant defiance of appeals coming from the UNESCO, the UN, the ICOMOS and many individual states.

Thus, the General Conference of the UNESCO 17 October 2003 proclaimed the Declaration concerning the International Destruction of Cultural Heritage, under Part 6 of which "a State that intentionally destroys or intentionally fails to take appropriate measures

20 Francioni-Lenzerini: op. cit. 20. 
to prohibit, prevent, stop and punish any intentional destruction of cultural heritage of great importance for humanity, whether or not it is inscribed on a list maintained by UNESCO or another international organization, bears the responsibility for such destruction to the extent provided for by international law".

This analysis leads us to conclude that the wilful and discriminatory destruction of the great Buddhas of Bamiyan perpetrated by the Taliban in March 2001 constitutes a breach of international law forbidding the wanton destruction of cultural heritage. Additionally, such destruction is a specific breach of the commitment under the World Heritage Convention to ensure the protection of cultural heritage located on the territory of State Parties.

The law of state responsibility is in practice an unlikely and ill-adapted mechanism for compelling a state to preserve cultural heritage situated on its territory. Jurisdictional hurdles make judicial proceedings notoriously difficult. As for countermeasures, it is unresolved whether they are available at all to those states invoking responsibility solely under Art. 48 of the Articles. Even if it were so, assessing proportionality might pose a bar, given that simple reciprocity in the form of damage by another state to cultural heritage found on their respective territories would be preposterous and possibly impermissible. State responsibility can only be invoked, once it has breached the relevant international obligation and by then, in most cases of damage to or destruction of cultural heritage, it is too late. Thus, in the great majority of cases, diplomatic pressure would be the only practicable option. As such, given that states not party to the world heritage convention are permitted to intervene diplomatically, if another state fails to preserve elements of the world's cultural heritage situated on its territory, it scarcely matters in practice that they are not entitled to compel preservation through the invocation of state responsibility. In practice, since diplomatic coercion is the only realistic course of action, it is perhaps immaterial that states which are parties to the World Heritage Convention may in principle invoke another's responsibility for failing to preserve this heritage. ${ }^{21}$

The mechanisms put in place by the Convention resulted in a reinforcement, on a global and national level, of the politics of protection that until then had been very unequally developed and rarely coherent from one region to the next. The UNESCO has no power to police or to sanction. Its authority is purely moral. It exercises its authority in various ways: persuasion or political pressure on governments, the classification of a site of heritage in peril, the promise of technical and financial assistance. In this way, it can stop the projects whose realization would bring grave, possibly irreparable effects to registered goods now or in the future. ${ }^{22}$ On the long list of avoided catastrophes, we should mention the prevention of the placement of a bauxite treatment factory near an archaeological site in Delphi, of the flooding of sites of rock art in the valley of Coa in Portugal by the construction of a dam, of the disfigurement of the plateau of Giza by the creation of a highway near the pyramids and of the immense saline construction on the site of El Vizcaino in Mexico or of cable car access for tourists in Machu Picchu. The UNESCO sometimes intervenes to support the action of small states in the face of powerful economic forces and sometimes to prevent governments from undertaking operations that could damage the integrity of protected 
monuments. ${ }^{23}$ The UNESCO plays a decisive role in raising awareness of a collective responsibility with regard to world heritage. ${ }^{24}$

Considering the high rate of ratifications of the World Heritage Convention as well as the authoritative character of UNESCO recommendations, which in effect represent nearly the totality of the nations of the world that participate in the General Conference, it is not possible to deny that a general opinio juris exists in the international community on the binding character of principles prohibiting the deliberate destruction of cultural heritage of significant importance for humanity. This conclusion is reinforced by the fact that the protection of cultural heritage as a matter of public interest, and not only as part of private property rights, is recognized in most of the advanced domestic legal systems in the world.

The concept of identifying and conserving the values of heritage places has been at the heart of the UNESCO Convention Concerning the Protection of the World Cultural and Natural Heritage 1972, and indeed, of all international heritage conservation policies. However, the application of the Convention in different countries with diverse cultural roots has been a key issue. Experience shows that only via the understanding of the influence of culture on an understanding of nature, with a complete assessment of the interrelationship of the two in theory and in practice, can world heritage be protected in a meaningful and holistic way. ${ }^{25}$

It should be mentioned that at present the expression "World Heritage" no longer has the same meaning as it did in 1972. It may be queried whether the aim of universalism is still the goal, when economic and financial logic penetrates and remodels the cultural sphere and tends to impose a "global model" of heritage as an alternative. ${ }^{26}$

Since 1994, as a result of the adoption of "Global Strategy", the World Heritage List has become more open to heritage that had not been presented on the List or had been rejected by the Committee some years before: cultural landscapes, modern architecture, railways, waterways and different kinds of industrial heritage. These new categories finding entry into World Heritage "reflect a significant change in our concept of heritage": by finally questioning the idea inherited from ancient times and firmly rooted in European culture of what a masterpiece is, "the World Heritage Committee opened the way to a more balanced view of humanity's heritage". ${ }^{27}$

The doctrinal consistency of world heritage is compromised by the difficulty of clearly articulating the relationship between universality and cultural diversity. ${ }^{28}$ For some years, the controversy has focused on the theme of "imbalance" or even "lack of representativity" of the List. At the same time, a double imbalance, geographic and thematic, persists. From the geographic point of view, in one region alone, that is, in Europe half of the cultural sites are inscribed on the List. The absence of inscribed African sites, whether archaeological or urban, devalues the List and even the concept of world heritage. The typology established produces a clear preponderance of three categories of cultural items that essentially pertain to European civilization: archaeological sites, historical cities, Christian monuments.

23 Ibid. 325.

24 Ibid. 327.

25 Dailoo, Sh. I.-Pannekoek, F.: Nature and Culture: A New World Heritage Context. International Journal of Cultural Property, 15 (2008) 25-47.

26 Musitelli: op. cit. 330.

27 Pressouyre, L.: The Past Is Not Just Made of Stone. UNESCO Courier, December, 2000. 19.

28 Musitelli: op. cit. 328. 
A broad consensus existed concerning the proposition that all reform steps must be achieved without changing the Convention. Amending the Convention would be a long and risky option and would result in the existence, for a period of undefined length, of two parallel conventions, a source of permanent and serious problems as to its implementation. ${ }^{29}$

The Committee acknowledged that cultural landscapes represent the "combined works of nature and of man" as formulated under Art. 1 of the Convention. They are illustrative of the evolution of human society and settlement over time under the influence of physical constraints and/or opportunities presented by their natural environment and of successive social, economic and cultural forces, both external and internal.

Certain sites reflect specific techniques of land use that guarantee and sustain biological diversity. Others associated in the minds of the communities with powerful beliefs, artistic and traditional customs embody an exceptional spiritual relationship of people with nature. So as to reveal and sustain the great diversity of the interactions between humans and their environment, to protect living traditional cultures and preserve the traces of those which have disappeared, these sites called cultural landscapes have been inscribed on the World Heritage List. Cultural landscapes (cultivated terraces on lofty mountains, gardens, sacred places) testify to the creative genius, social development, imaginative and spiritual vitality of humanity. They are part of our collective identity.

To date, 55 properties have been included as cultural landscapes in the World Heritage List, such as: Australia - Uluru-Kata Tjuta National Park (1987), Austria Hallstatt-Dachstein Salzkammergut Cultural Landscape (1997), Wachau Cultural Landscape (2000), Hungary - Hortobágy National Park - the Puszta (1999), Tokaj Wine Region Historic Cultural Landscape (2002), Italy - Sacri Monti of Piedmont and Lombardy (2003), Cilento and Vallo di Diano National Park with the Archaeological Sites of Paestum and Velia and the Certosa di Padula (1998), Costiera Amalfitana (1997), Portovenere, Cinque Terre and the Islands (Palmaria, Tino and Tinetto) (1997), Val d'Orcia (2004), Philippines - Rice Terraces of the Philippine Cordilleras (1995), Poland - Kalwaria Zebrzydowska: the Mannerist Architectural and Park Landscape Complex and Pilgrimage Park (1999), Portugal - Alto Douro Wine Region (2001), Cultural Landscape of Sintra (1995), Landscape of the Pico Island Vineyard Culture (2004), South Africa - Mapungubwe Cultural Landscape (2003), Spain - Aranjuez Cultural Landscape (2001), Sweden - Agricultural Landscape of Southern Öland (2000), Togo - Koutammakou, the Land of the Batammariba (2004), United Kingdom of Great Britain and Northern Ireland - Blaenavon Industrial Landscape (2000), Cornwall and West Devon Mining Landscape (2006), Austria, Hungary - Fertö/ Neusiedlersee Cultural Landscape (2001), Germany, Poland - Muskauer Park / Park Muzakowski 2004) and so on.

In 1992, the World Heritage Convention became the first international legal instrument to recognize and protect cultural landscapes. The Committee at its $16^{\text {th }}$ session adopted guidelines concerning their inclusion in the World Heritage List.

Intentions to introduce reforms in the implementation of the Convention and to render its contemporary interpretation are almost as old as the Convention itself and have transformed the World Heritage Programme into a forum of permanent discussion, evaluation and intervention. An increasing number of State Parties and sites will not only contribute to an enhanced and more global approach in identifying and addressing problems, 
but will also turn the reform procedure into a more complex and time-consuming task. On the other hand, greater awareness of the specific problems of World Heritage and increasing demands for changes might accelerate the reform procedure. The elaboration and implementation of the globally important and recognized World Heritage program can continue to be successful only as long as the different entities concerned by the Convention, scilicet, the State Parties, the Committee, its Bureau and the advisory bodies cooperate closely by applying clear legal provisions, concepts and strategies. ${ }^{30}$

In particular, the concept of World Heritage lacks the support of an encompassing conception of culture that takes into account the facts of anthropology. This results in the crystallization of the artificial distinctions between natural and cultural goods, material remains and spiritual values, history and authenticity. The rigidity of these categories, which lack pertinence in most non-European civilizations, has privileged the classic architectural heritage-grand monuments and urban areas that are charged with history-to the detriment of forms of heritage that integrate intangible values, such as sacred sites, traditional habitats, religious or merchant routes. ${ }^{31}$

There are civilizations for which the notion of heritage is not the same as the notion of monuments. The efforts made by world heritage organs to integrate this dimension of the problem, which exposes representations and a symbolic system unfamiliar to Western paradigms, remain too timid to adsorb the contradiction between universality and diversity. Even if the trend has evolved favourably since 1972, there still remains resistance to surpass pure monuments and an elitist conception to avoid an approach that would integrate the heritage within its environment. ${ }^{32}$

At the same time, experiences at international level can influence national practices. In this variegated landscape, it becomes crucial to verify whether there is a conflict or coherence between different treaty regimes protecting cultural heritage on the one hand and investors' rights on the other hand. ${ }^{33}$

The scientific relevance of representativity in relation to heritage can always be contested. The reality of imbalance and the ethnocentric grievance it encourages has given rise in recent years to the supposition of north-south tensions. This evolution would be very harmful if, in the name of a "politically correct" concept of world heritage, each state or each cultural community believed in its right to claim a quota of sites in the enforcement of a presumed right of the representativity of its heritage or even its powers of negotiation. If it were not based on scientific premises, the representativity of World Heritage would risk being reduced to questionable political arithmetic. ${ }^{34}$

The corpus of norms largely elaborated by the UNESCO itself does not appear to need radical renewal. What is needed is its radical application. In particular, basic guidelines concerning taking stock of the cultural heritage, training qualified personnel and the holistic management of heritage resources are still not adequately respected.

It will be necessary to integrate research from social sciences and humanities, in particular from the area of history by bringing universities, research institutes and religious authorities into the picture and into constructive dialogue with classical studies departments

30 Strasser: op. cit. 255.

31 Musitelli: op. cit. 329.

32 Ibid. 330.

33 Vadi, Valentina Sara: Cultural Heritage and International Investment Law: A Stormy Relationship. International Journal of Cultural Property, Vol. 15. 1-24.

34 Musitelli: op. cit. 330. 
and other 'guardian' institutions as well as with the media and educational authorities. Each society will need to assess the nature and precariousness of its cultural as well as natural heritage in its own terms and determine the uses it wishes to make of both and the links it might build between them. Within nations, therefore, it is particularly important that this sort of heritage is recognised by and for all groups (women, children, cultural minorities including Indigenous Peoples). Equally, the means to do this work needs to be specified not just by the central organs of the state, but also, perhaps above all by municipalities and regions. The method employed should draw on current experience and new knowledge not just to conserve, but also to establish meaningful connections between past and present, East and West, North and South, tangible and intangible values, culture and nature.

\section{Summary}

The presentation is devoted to legal issues related to the conception of World Cultural and Natural Heritage and the tendency of its development within the frameworks of international law. We've provided the analysis of international legal relations among the Parties to the Convention Regarding the Protection of the World Cultural and Natural Heritage of 1972, the Intergovernmental Committee for the Protection of the World Cultural and Natural Heritage and the Fund for the Protection of the World Cultural and Natural Heritage regarding protection, conservation, presentation, and transmission to future generations of cultural and natural objects included in the World Heritage List. The items protected by the Convention are those pertaining to the cultural or natural heritage, which are of outstanding universal value from the point of view of history, art, science or aesthetics.

The Convention lays down two basic principles, which are at the same time the basis of the World Heritage Conception. First, each State Party to the Convention recognizes that the duty of ensuring conservation of the elements of World Heritage situated on its territory lies primarily with it and undertakes to act to this end to the utmost of its own resources. World Heritage sites belong to all the peoples of the world, irrespective of the territory on which they are located. Secondly, all the Contracting States recognize that it is the duty of the international community as a whole to cooperate in ensuring the conservation of a heritage, which is of universal character.

At the moment, the expression "World Heritage" no longer has the same meaning as it did back in 1972 because of globalization and commercialization. We argue that the conceptual focus has shifted alongside interrelated and complementary directions: from monuments to people; from objects to functions; from preservation per se to purposeful preservation, sustainable use and development. Reappearing functional heritage is discussed as opposed to the objectified heritage of the past by referring to both practical and theoretical heritage domains.

If today's collective memory is to be shared more widely and more creatively to form that of future generations, broader participation appears essential. But this will be possible only if people themselves have a better understanding of their heritage. Hence the paramount need for inventories of heritage which are not only more complete, but also more meaningful. As it was pointed out by the World Heritage Committee, the knowledge basis for the elaboration of integrated conservation policy remains scarce in many countries. Governments need to examine more comprehensively what society defines as heritage and raise awareness of its value. 